\title{
Floodplain simulation for Musi River using integrated 1D/2D hydrodynamic model
}

\author{
Muhammad B. Al Amin ${ }^{1, *}$, Sarino ${ }^{1}$, and Helmi Haki ${ }^{1}$ \\ ${ }^{1}$ Civil Engineering Department, Faculty of Engineering, Sriwijaya University, 30662 Indralaya, Indonesia
}

\begin{abstract}
This paper presents the simulation of floodplain at Musi River using integrated 1D and 2D hydrodynamic model. The 1D flow simulation was applied for the river channel with flow hydrograph as upstream boundary condition. The result of 1D flow simulation was integrated into 2D flow simulation in order to know the area and characteristics of flood inundation. The input data of digital terrain model which was used in this research had grid resolution of $10 \mathrm{mx} 10 \mathrm{~m}$, but for $2 \mathrm{D}$ simulation the resolution was with grid resolution $50 \mathrm{~m} \times 50 \mathrm{~m}$ so as to limit simulation time since the model size was big enough. The result of the simulation showed that the inundated area surrounding Musi River is about $107.44 \mathrm{~km}^{2}$ with maximum flood depth is $3.24 \mathrm{~m}$, water surface velocity ranges from 0.00 to $0.83 \mathrm{~m} / \mathrm{s}$. Most of floodplain areas varied from middle to high flood hazard level, and only few areas had very high level of flood hazard especially on river side. The structural flood control measurement to be recommended to Palembang is to construct flood dike and flood gate. The non structural measurement one is to improve watershed management and socialization of flood awareness.
\end{abstract}

\section{Introduction}

Musi River is one of big rivers in Indonesia flowing from Bengkulu to South Sumatra Province with a total length of about $760 \mathrm{~km}$. The tides of Musi River normally cause inundation in several locations particularly around the river within Palembang which is one of cities crossed by Musi River with a low topography and relatively flat areas. Besides that, the inundation may be higher during rainfall season due to high rainfall intensities and also increased runoff which is caused by land use changes of most of undeveloped areas to be developed ones [1]. Besides that, Palembang does not have yet adequate flood control measures, such as flood dike and gates. These conditions make Palembang as the capital city of South Sumatra is prone to flood [2].

To design the flood control and management, the information like flooded area map is needed so that the area exposed to flood impact can be identified [3-5]. Unfortunately, such data and map are not available. This paper presents the simulation of floodplain of inundated areas around Musi River within Palembang City by using integrated $1 \mathrm{D} / 2 \mathrm{D}$ hydrodynamic model. The simulation results are the estimation of the characteristics of flooded area (area, depth, and velocity) and flood hazard classification of floodplain around the river that can be used by Palembang Municipality regarding urban flood control and management program.

Flood is natural process and can be defined as water overflow over stream bank. Floodplain is an area at river side which is flooded during high water flow, but dry during normal condition [6-8]. The boundary of flooded area can be determined by 100 -yr flood discharge $[6,7]$.

The 1D flow model in most practice is generally used in the case where flow passes through prismatic channel. But, for non prismatic channel (i.e., channel with varying cross section and alignment) such as river, flow of dam break, or lateral flow through dike failure, and river overflow, the use of 2D flow becomes better model which results in accurate estimation $[9,10]$. Some of the examples of $1 \mathrm{D}$ and $2 \mathrm{D}$ in flood flow modelling were explained in detail in [11-19].

The advantages of 1D model is the ability to calculate quickly with small computer memory, whereas 2D model needs bigger memory especially for big one [18-20]. The 1D model is widely used for flood water level and flow rate simulation within channel, meanwhile 2D model is used for overland flow on floodplain $[4,33]$. The channel and hydraulic structures requires the energy equation (also known as Bernoulli's equation) to calculate the head loss, while the floodplain requires the depth-averaged Saint-Venant equations to calculate multi-directional flow patterns [33]. Studies have showed the integration of 1D/2D model (1D model for river channel and 2D model for floodplain) can help calculate quickly and give accurate result in flood flow simulation specifically flood inundation [21, 22]. Besides that, $1 \mathrm{D} / 2 \mathrm{D}$ flow simulation can provide information about spatial flood risk like the depth, inundation duration and flow velocity during the flood [23]. The illustration of general integrated 1D/2D flow model is shown in Figure 1. Some of the researches which were done previously concerning flood flow

\footnotetext{
* Corresponding author: baitullah@unsri.ac.id
} 
simulation with integrated $1 \mathrm{D} / 2 \mathrm{D}$ model are presented in $[10,20,21,23-25]$.

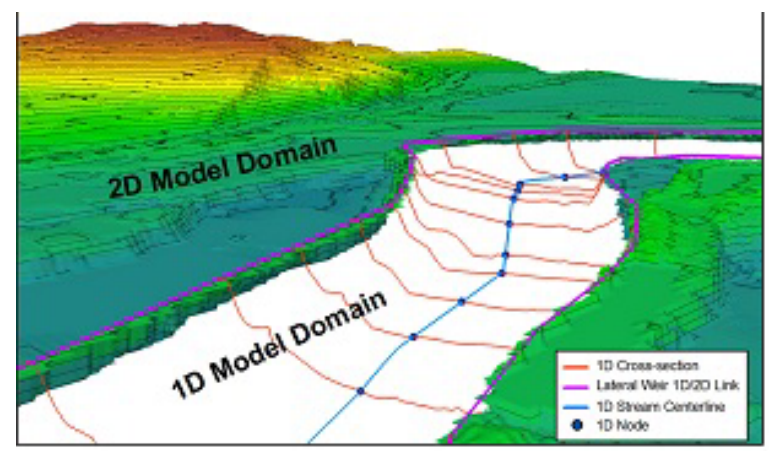

Fig. 1. Illustration of general 1D model of the river channel integrated with a 2D model of the floodplain [33]

\section{Method}

This research was done in Musi River within Palembang City $\left(400,61 \mathrm{~km}^{2}\right)$, South Sumatra Province, Indonesia which is located between $2^{\circ} 52^{\prime}-3^{\circ} 5^{\prime}$ South latitude and $104^{\circ} 37^{\prime}-104^{\circ} 52^{\prime}$ East longitude as shown at Figure 2. Besides the river, there are other three big rivers flowing across Palembang namely: Keramasan, Ogan and Komering River whose flow rate and flood level were also calculated in this research. The width of Musi River crossing Palembang City ranges from 247.18 to $1,089.56$ $\mathrm{m}$, whereas Keramasan, Ogan, and Komering River consecutively ranges from 76.49 to $183.28 \mathrm{~m}, 144.44$ to $295.65 \mathrm{~m}$, and 85.03 to $189.60 \mathrm{~m}$. In addition to that, there are also 18 subsystems or sub catchment areas in which the stream flow goes laterally to Musi River. Figure 3 shows the Musi River subsystems in the research location.

Most areas of Palembang City consist of housing and swamp. In 2013, about 52.56\% area of Palembang was dominated by vegetated land, $25.34 \%$ built-up area, $8,4 \%$ barren land, and $13.70 \%$ water body [1]. Figure 4 shows the land use of Palembang City in detail. Topographic condition of Palembang is mostly flat area and the elevation is between 0.00 to $36.00 \mathrm{~m}$ above mean sea level (MSL). The average slope is 2.02 percent. Figure 5 shows the digital terrain model (DTM) map of Palembang.

Flood Modeller, a hydrodynamic model, had been released by $\mathrm{CH} 2 \mathrm{M}$ was used in this research. The model can simulate flood inundation by integrating $1 \mathrm{D}$ and $2 \mathrm{D}$ flow model. Indeed there are other hydrodynamic models which can be used such as XP-SWMM [26, 27], TUFLOW [26], Flo-2D [28, 29], SOBEK-OVERLAND FLOW [4], Delft1D2D [21], LISFLOOD-FP [30], and the familiar HEC-RAS [10, 31]. But, Flood Modeller was applied as in the computation phase of $2 \mathrm{D}$ flow using solver alternating direction implicit (ADI) which was quick and stable [25].

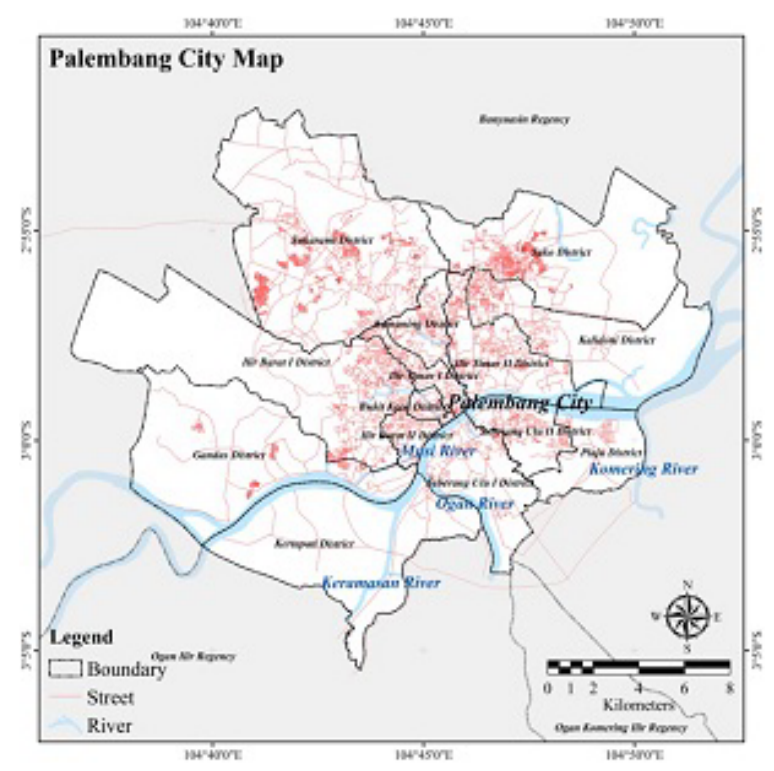

Fig. 2. Location of research

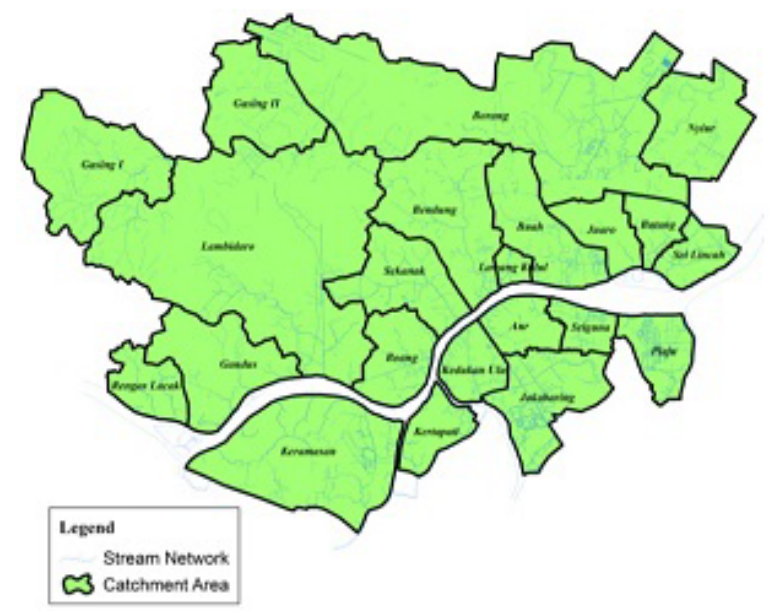

Fig. 3. Musi subsystems within Palembang City

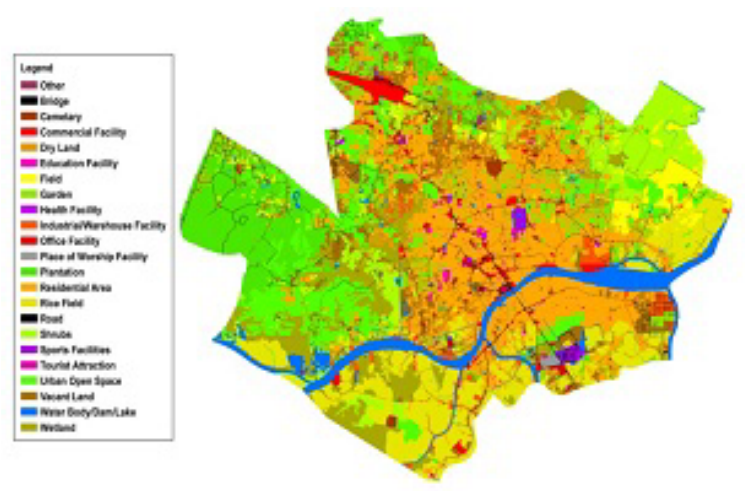

Fig. 4. Land use map 


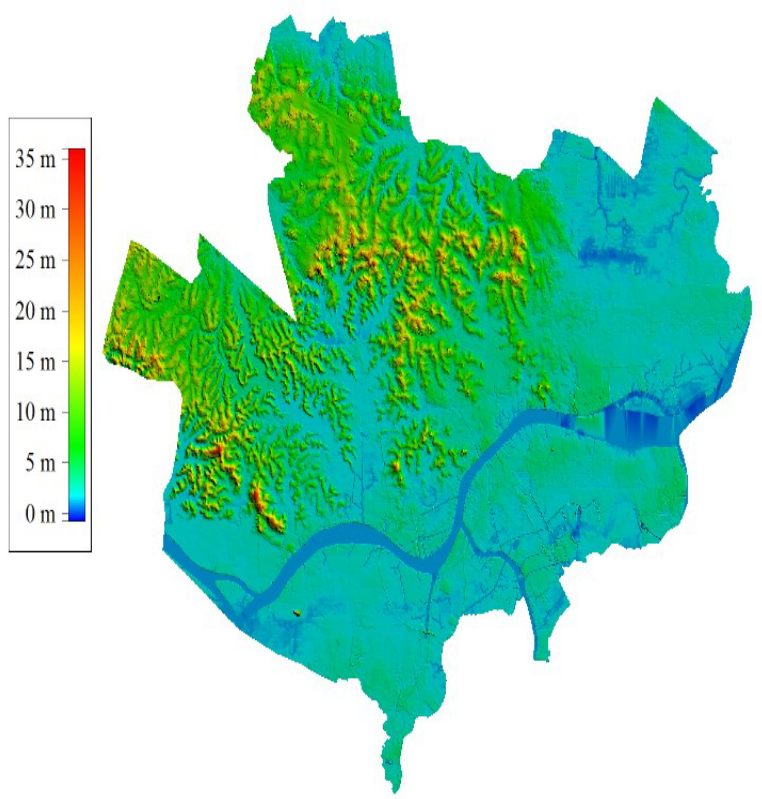

Fig. 5. Digital terrain model (DTM)

In general, phase of modelling included: 1) input of river geometry data such as river cross section, distance between cross sections, and river roughness coefficient; 2) entry of boundary conditions such as hydrograph for upstream boundary, stage hydrograph for downstream boundary and lateral inflow for boundary along the river; 3) 1D flow simulation; 4) input of 2D active area; 5) integration of $1 \mathrm{D}$ and 2D geometry; 6) 1D/2D model simulation; 7) visualization of simulation results.

The river cross sections were obtained by bathymetric survey with distance between cross sections of $200-600 \mathrm{~m}$ along $27 \mathrm{~km}$ Musi River, $2.4 \mathrm{~km}$ Keramasan River, $6.3 \mathrm{~km}$ Ogan River, and $2.5 \mathrm{~km}$ Komering River then the results were imposed into the model.

The flow velocities and water levels were measured in order to calculate flow rate of the rivers as upstream boundary condition, while the highest tide level was used as downstream boundary condition.

The 100-yr return period of direct runoff hydrographs from 18 Musi subsystems within Palembang were used as lateral inflows along the river. These hydrographs were resulted from hydrologic analysis.

The 1D simulation used 1 second time step within 24 hours. For 2D flow simulation, the grid size used in the model was $50 \mathrm{~m} \mathrm{x} 50 \mathrm{~m}$ in order to limit time needed to do simulation due to big simulation model.

\section{Result and discussion}

The schematic of modelled system in Flood Modeller is presented in Figure 6, where the geometric model consisted of river sections, junctions, 2D active area, whereas flow component comprises of flow-time boundary, tidal boundary, and lateral inflow.

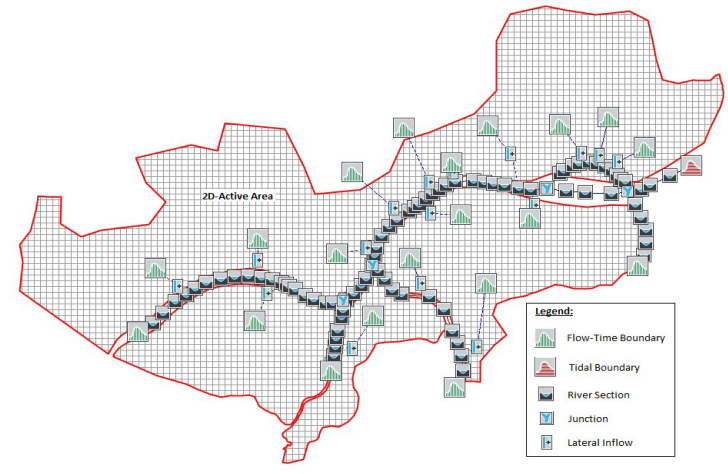

Fig. 6. Schematic of modelled system

\subsection{Boundary conditions}

The flow rate as flow hydrograph was used as boundary condition for upstream of the river, while the tide level as stage hydrograph was used for downstream one. The flow rates in the upstream of Musi River, Ogan River, and Komering River respectively are $1,557.74 \mathrm{~m}^{3} / \mathrm{s}$, $77.77 \mathrm{~m}^{3} / \mathrm{s}, 302.89 \mathrm{~m}^{3} / \mathrm{s}$, and $77.09 \mathrm{~m}^{3} / \mathrm{s}$ which were assumed to be constant, whereas the highest tide level of downstream was $+2.95 \mathrm{~m}$ from mean sea level (MSL) which is also assumed constant.

Direct runoff (DRO) hydrographs from 18 subsystems along Musi River were used as lateral inflow hydrographs. The hydrographs were resulted from hydrologic analysis using SCS synthetic hydrograph with 100-yr design rainfall. The direct runoff of each subsystem is presented in Figure 7.

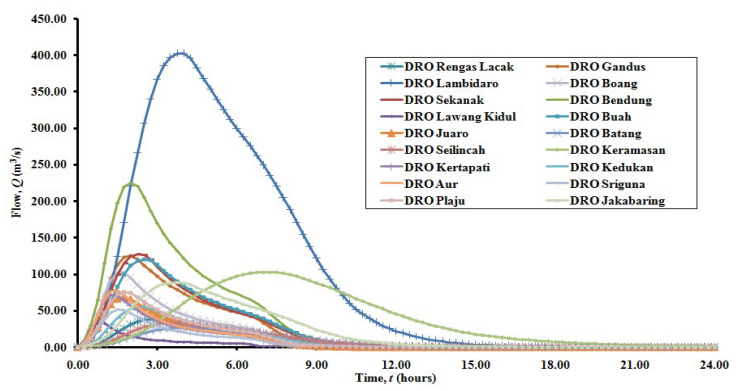

Fig. 7. Direct runoff hydrographs from subsystems

\subsection{Area and depth of inundation}

The result of simulation which shows distribution of inundation depth around Musi River is presented in Figure 8 to 11. Figure 8 shows the area and depth of inundation at 6th hour of the simulation, whereas Figures 9 to 11 show the area and depth of inundation at hour 12 , 18 , and 24 respectively.

Figure 12 shows area and depth of inundation at maximum condition. In detail, in Figures 8 to 11 , it can be seen that the flooded area increasing. The maximum flooded area (Figure 12) resulted from analysis is about $107.44 \mathrm{~km}^{2}$ with the flood depth ranges from 0.00 to $3.24 \mathrm{~m}$. 


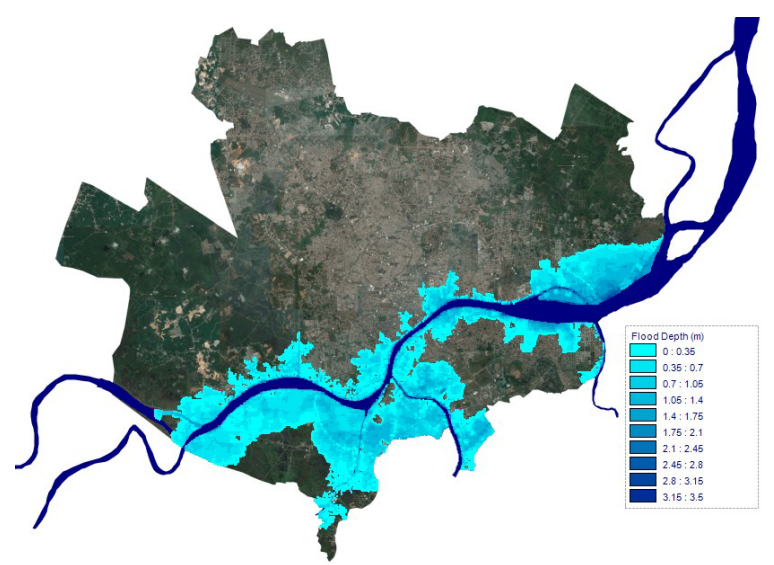

Fig. 8. Flood depth at 6th hour $\left(A=64.89 \mathrm{~km}^{2} ; d=0.00 \mathrm{~m}-\right.$ $3.01 \mathrm{~m})$

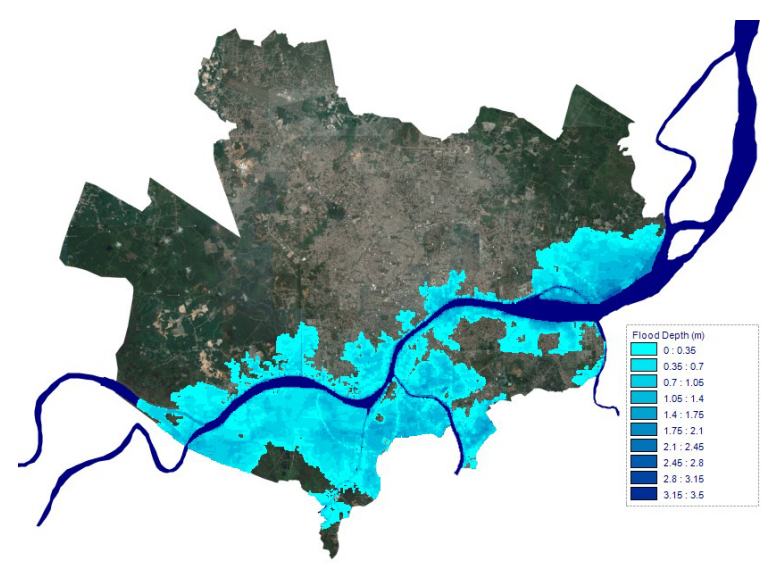

Fig. 9. Flood depth at 12 th hour $\left(A=82.44 \mathrm{~km}^{2} ; d=0.00 \mathrm{~m}-\right.$ $3.01 \mathrm{~m})$

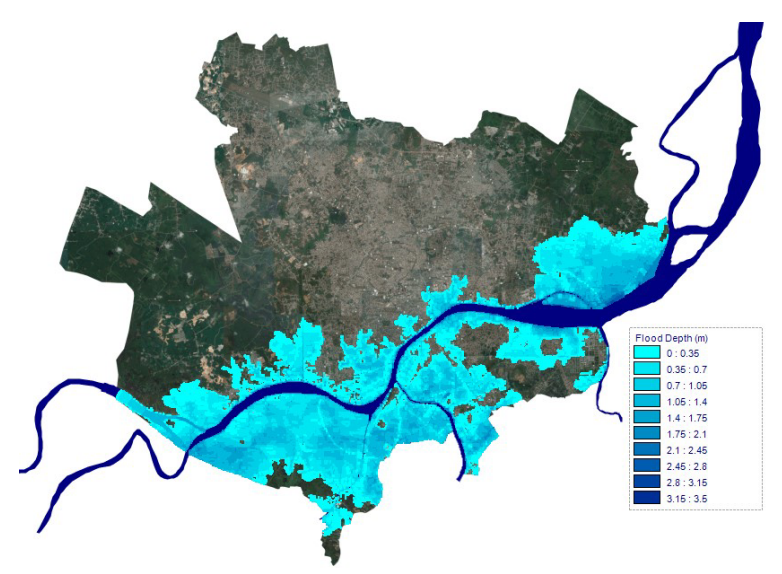

Fig. 10. Flood depth at 18 th hour $\left(A=94.19 \mathrm{~km}^{2} ; d=0.00 \mathrm{~m}-\right.$ $3.01 \mathrm{~m})$

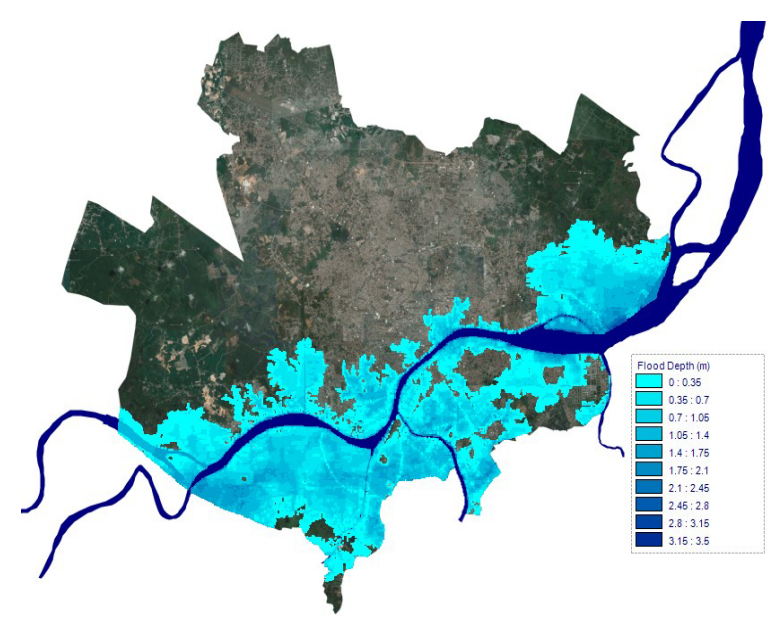

Fig. 11. Flood depth at 24th hour $\left(A=103.88 \mathrm{~km}^{2} ; d=0.00 \mathrm{~m}\right.$ $-3.01 \mathrm{~m})$

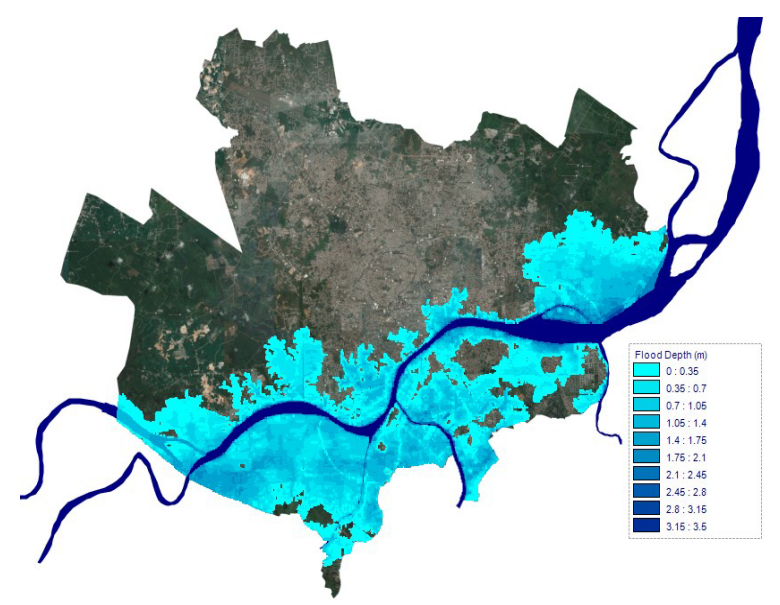

Fig. 12. Maximum flood depth $\left(A=107.44 \mathrm{~km}^{2} ; d=0.00 \mathrm{~m}-\right.$ $3.24 \mathrm{~m})$

\subsection{Velocity of flood flow}

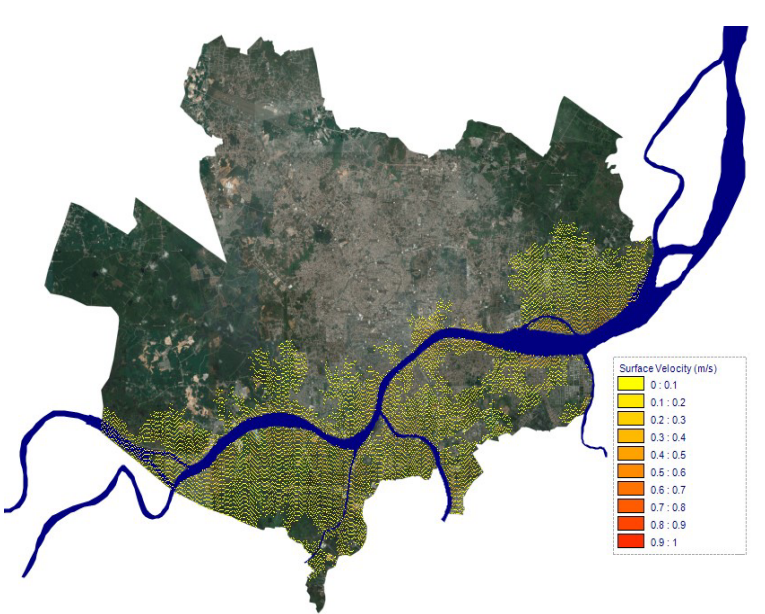

Fig. 13. Maximum velocity on floodplain $(v=0.00 \mathrm{~m} / \mathrm{s}-0.83$ $\mathrm{m} / \mathrm{s})$ 
The maximum velocity of the flood flow is showed in velocity vector as shown in Figure 13. The velocity ranges between 0.00 to $0.83 \mathrm{~m} / \mathrm{s}$ which depends on the flood flow and water depth. The flow velocity is also influenced by the distance of certain point or location from the river. The farther the distance from the river, the lesser the velocity due to energy losses caused by friction with the bed surface.

\subsection{Flood hazard}

The classification of flood hazard which was used in this research is derived from [32], where flood hazard rate is as function of flood depth, flow velocity, and debris factor which can be expressed as:

$$
H R=d x(v+n)+D F
$$

where:

$H R$ : flood hazard rating

$d \quad$ : depth of flooding (m)

$v \quad:$ velocity of floodwaters $(\mathrm{m} / \mathrm{s})$

$D F \quad$ : debris factor

$n \quad$ : a constant of 0.5

The debris factor varies and depends on flood depth, flow velocity, and land use. For urban land use, the debris factor was determined as:

$$
\begin{aligned}
& D F=0, \text { if } d \leq 0.25 \mathrm{~m} \\
& D F=1, \text { if } d>0.25 \mathrm{~m} \text { and or if } v>2 \mathrm{~m} / \mathrm{s}
\end{aligned}
$$

The flood hazard classification was classified into four stages i.e., low, moderate, significant, and extreme. It was low if $H R<0.75$, moderate if $0.75<H R<1.25$, significant if $1.25<H R<2.5$, and extreme if $H R>2.5$.

The result of classification of flood hazard is shown in Figure 14. The figure shows that most of floodplain areas have moderate to significant flood hazard, while few have low flood hazard and the rest have extreme one particularly at areas exactly at riverside.

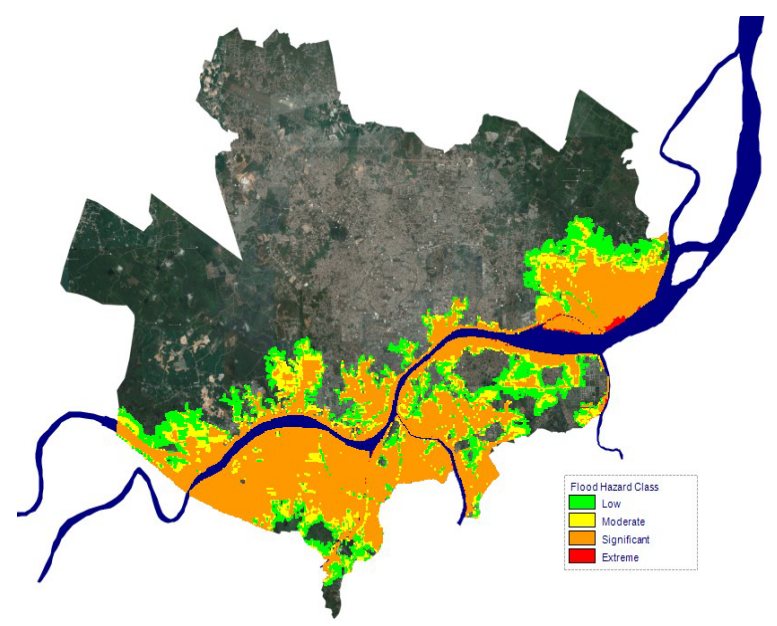

Fig. 14. Flood hazard classification

\section{Conclusions and recommendation}

From result and above discussion, it can be concluded that based on simulation of integrated $1 \mathrm{D} / 2 \mathrm{D}$ hydrodynamic model, the floodplain area of the Musi River in Palembang City is about $107.44 \mathrm{~km}^{2}$, with maximum flood depth between 0.00 to $3.24 \mathrm{~m}$, and flow velocity between 0.00 to $0.83 \mathrm{~m} / \mathrm{s}$. Most of areas adjacent to Musi River have moderate to significant flood hazard level, and few areas have low one, while the rest have extreme one.

It is recommended for Palembang Municipality for urban flood control and management program to construct flood dike and tide gate to prevent overflow and backwater from Musi River as structural measurement, to control the land use and promote socialization of flood hazard awareness at flooded area as nonstructural measurements.

The authors highly appreciate Engineering Faculty of Sriwijaya University who had supported and funded this research. Then the authors also thanked Palembang City Board of Planning for having provided data.

\section{References}

1. M. B. Al Amin, Sarino, and H. Haki., Proceeding of The 8th National Seminar of AVoER (Engineering Faculty, Sriwijaya University, Palembang, Indonesia, 2016)

2. M. B. Al Amin, Sarino, and R. S. Ilmiaty. Proceeding of 5th International Seminar of HATHI (Denpasar, Indonesia, 2016)

3. S. Ghimire, Climate, 1, 148-162 (2013)

4. M. G. F. Werner, Hydrology and Earth System Sciences, 8(6), 1141-1152 (2004)

5. D. Zhang, et. al., Water Science and Engineering, 8(3), 195-204 (2015)

6. S. L. Dingman. Fluvial Hydraulics (Oxford University Press, New York, 2009)

7. FEMA-Region 10. Floodplain Management - NFIP Guidebook (2009)

8. L. W. Mays. Water Resources Engineering (John Wiley \& Sons, Inc., New York, 2001)

9. M. H. Chaudry. Second Edition Springer Science+Business Media, LLC, New York, (2008)

10. V. M. Quiroga, S. Kure, K. Udo, and A. Mano, RIBAGUA - Revista Iberoamericana del Agua, 3, 25-33 (2016)

11. S. Ahmad, and S. P. Simonovic, Final Report Natural Resources Institute Facility for Intelligent Decision Support University of Manitoba, Canada, (1999)

12. R. J. Connell, D. J. Painter, and C. Beffa, Journal of Hydrologic Engineering, 6(5), 406-415 (2001)

13. E. M. Ruji, Master Thesis International Institute for Geo-Information Science and Earth Observation, Enschede, The Netherlands (2007)

14. A. C. Cook, Master Thesis Purdue University, West Lafayette, Indiana (2008)

15. P. Vanderkimpen, E. Melger, and P. Peeters, Taylor \& Francis Group, London, , 77-84, (2009) 
16. D. Gilles, and M. Moore, University of Iowa, College of Engineering, (2010)

17. N. J. Lim, Performance and uncertainty estimation of 1- and 2-dimensional flood models, Bachelor Thesis (Akademin För Teknik Och Miljö, Högskolan I Gävle, 2011)

18. L. T. Chargel, and M. A. G. Massera da Hora, Global Journal of Researches in Engineering: E, Civil and Structural Engineering, 14(2), 67-75 (2014)

19. M. Gharbi, A. Soualmia, D. Dartus, and L. Masbernat, J. Mater. Environ. Sci., 7(8), 3017-3026 (2016)

20. J. Leandro, A. S. Chen, S. Djordjević, and D. A. Savić, Journal of Hydraulic Engineering, June, 495504 (2009)

21. E. Frank, A. Ostan, M. Coccato, and G. S. Stelling, Ecology and Environment, 50 (2001)

22. D. Dutta, J. Alam, K. Umeda, M. Hayashi, and S. Hironaka, Hydrol. Process., 21, 1223-1237 (2007)

23. X. Fang, and D. Su, Journal of American Water Resources Association, June, 713-724 (2006)
24. A. R. Faz, A. Meller, and G. B. L. Silva, 12nd International Conference on Urban Drainage (Porto Alegre/Brazil, 2011)

25. R. Ahmadian, R. A. Falconer, J. Wicks, Journal of Flood Risk Management, 1-15 (2015)

26. B. C. Phillips, S. Yu, G. R. Thompson, N. de Silva, 10th International Conference on Urban Drainage (Copenhagen/Denmark, 2005)

27. M. Morita, Water, 6, 253-270 (2014)

28. J. S. O'Brien, P. Y. Julien, and W. T. Fullerton, Journal of Hydraulic Engineering, 119(2), 244-261 (1993)

29. J. S. O'Brien, and W. T. Fullerton, USDA Forest Service Proceedings RMRS-P-7, 52-60 (1999)

30. M. Wilson, P. Bates, D. Alsdorf, B. Forsberg, M. Horrit, J. Melack, F. Frappart, and J. Famiglietti, American Geophysical Union, 34, 1-10 (2007)

31. G. Di Baldassarre. Floods in a Changing Climate (Cambridge University Press, New York, 2012)

32. Defra, R\&D Technical Report FD2320/TR2 (2005)

33. D. Gilles, et. al., Water, 4(1), 85-106 (2012) 